\title{
PENGARUH REBUSAN KAYU MANIS TERHADAP PERUBAHAN KADAR TRIGLISERIDA PADA PREDIABETES DI KOTA MAKASSAR
}

\section{THE EFFECT OF SWEET WOOD DRAWING ON THE CHANGES OF TRIGLICERIDES LEVELS IN PREDIABETES IN MAKASSAR CITY}

\author{
Andi Nur Hudaya ${ }^{1,2}$, Nurhaedar Jafar ${ }^{2}$, Ridwan Thaha ${ }^{2}$, Veni Hadju ${ }^{2}$,Healthy \\ Hidayanti ${ }^{2}$, Abdul Salam ${ }^{2}$ \\ (Email/Hp: andinurhudayasaelong @gmail.com/085269352372) \\ ${ }^{1}$ Puskesmas Cangadi, Kabupaten Soppeng, Sulawesi Selatan \\ ${ }^{2}$ Program Studi Ilmu Gizi, Fakultas Kesehatan Masyarakat, Univesitas Hasanuddin, \\ Makassar
}

\begin{abstract}
ABSTRAK
Pendahuluan: Prediabetes merupakan fase sebelum diabetes melitus tetapi jika tidak dicegah dapat menyebabkan komplikasi seperti hipertrigliserida, di Kota Makassar jumlah hipertrigliserida meningkat dari 40,13\% tahun 2017 menjadi 43,70\% pada tahun 2018 . Tujuan: Penelitian ini bertujuan untuk mengetahui pengaruh rebusan kayu manis terhadap perubahan kadar trigliserida pada prediabetes di Kota Makassar. Metode: Desain Penelitian quasi ekserimen. Model rancangan adalah non randomized pre test post test with control group. Sebagai sampel mereka yang mengalami prediabetes dan didapatkan dari hasil skreening di masyarakat. Penelitian ini menggunakan kelompok intervensi ( $\mathrm{n}=14$ orang) yaitu yang diberikan rebusan dan edukasi kayu manis, sedangkan kelompok kontrol ( $\mathrm{n}=14$ orang) hanya diberikan edukasi kayu manis. Analisis data menggunakan uji t- paired test untuk mengetahui besar perubahan dan uji t- independent untuk mengetahui besar perbedaan antara kedua kelompok. Hasil: Hasil penelitian menunjukkan sebagian besar sampel perempuan $(89,28 \%)$, berumur 51-60 tahun, hampir semuanya obesitas sentral $(92,86 \%)$, mempunyai riwayat keluarga diabetes melitus $(71,43 \%)$ dan pendidikan sebagian besar perguruan tinggi $(42,86 \%)$. Hasil uji t berpasangan menunjukkan tidak ada perubahan kadar trigliserida yang signifikan sebelum dan sesudah intervensi rebusan kayu manis $(\mathrm{p}=0,109)$, demikian juga pada kelompok kontrol tidak ada perubahan kadar trigliserida sebelum dan sesudah pemberian edukasi $(p=0,279)$. Terjadi peningkatan pengetahuan yang signifikan $(p=0,001)$ setelah diberikan edukasi pada kelompok intervensi dan kelompok kontrol. Tidak ada perbedaan asupan energi, karbohidrat, protein, lemak dan serat sebelum dan sesudah pemberian rebusan kayu manis (intervensi) dan pemberian edukasi (control). Kesimpulan: Tidak ada perubahan kadar trigliserida yang signifikan sebelum dan sesudah konsumsi rebusan kayu manis pada prediabetes. Untuk penelitian berikutnya diharapkan menambah dosis kayu manis dan pemberiaannya lebih lama agar pemberian rebusan kayu manis efektifitas.
\end{abstract}

Kata Kunci : Prediabetes, Trigliserida, Kayu Manis 


\section{ABSTRACT}

Introduction: Prediabetes is a phase before diabetes mellitus but if it is not prevented it can cause complications such as hypertriglyceride, in Makassar the amount of hypertriglyceride increased from $40.13 \%$ in 2017 to $43.70 \%$ in 2018. Purpose: This study aims to determine the effect of wood stew sweet against changes in triglyceride levels in prediabetes in Makassar. Methods: Quasi-experimental research design. The design model is non randomized pre test post test with control group. As a sample of those who experienced prediabetes and obtained from screening results in the community. This study used an intervention group $(n=14$ people $)$ namely those given cinnamon stew and education, while the control group ( $n=14$ people) were only given cinnamon education. Data analysis used the t-paired test to find out the magnitude of change and the t-independent test to find out the difference between the two groups. Results: The results showed the majority of female samples (89.28\%), aged 51-60 years, almost all of them were central obesity (92.86\%), had a family history of diabetes mellitus (71.43\%) and most of the college's education (42.86\%). Paired t-test results showed no significant changes in triglyceride levels before and after the cinnamon stew intervention $(p=0.109)$, likewise in the control group there were no changes in triglyceride levels before and after educational provision $(p=0.279)$. There was a significant increase in knowledge $(p=0.001)$ after education was given to the intervention and control groups. There is no difference in energy, carbohydrate, protein, fat and fiber intake before and after administration of cinnamon stew (intervention) and education (control). Conclusions: There were no significant changes in triglyceride levels before and after consumption of cinnamon stew in prediabetes. The next research is expected to increase the dose of cinnamon and give it a longer duration so that the administration of cinnamon stew is effective.

\section{Keywords: Prediabetes, Triglycerides, Cinnamon}

\section{PENDAHULUAN}

Penyakit tidak menular salah satu penyebab kematian utama di dunia. Menurut data WHO, 2018 sebesar 36 juta orang meninggal akibat penyakit tidak menular setiap tahun ${ }^{1}$. Menurut International Diabetes Federation (IDF) dan American Heart Association/National Heart, Lung and Blood Institute (AHA/NHLBI) kriteria sindroma metabolik yaitu apabila seseorang terdapat sedikitnya tiga dari lima komponen, yaitu obesitas sentral, peningkatan tekanan darah, penurunan kadar kolesterol HDL (high-densit lipoprotein), peningkatan kadar trigliserida, dan peningkatan glukosa darah puasa ${ }^{2}$.

Berdasarkan data, penderita penyakit diabetes sebanyak 10,3 juta jiwa. Hasil Riset Kesehatan Dasar (Riskesdas) Tahun 2018 menunjukkan bahwa prevalensi penyandang diabetes naik menjadi 8,5\%, dari 6,9\%.(5) pada tahun 2045, jumlah orang dengan 20-79 tahun IGF diproyeksikan meningkat menjadi 587 (384,4-992,7) juta atau 8,3\% (5,6-13,9\%) dari populasi orang dewasa. Tidak ada perbedaan dalam keseluruhan IGT prevalensi untuk orang usia 20-79 tahun antara wanita (7,3\%) dan laki-laki (7,3\%) sedangkan prevalensi IGT sedikit lebih tinggi pada pria daripada wanita untuk orang lebih dari 50 tahun, dan untuk orang yang lebih muda dari 45 tahun, prevalensi IGT sedikit lebih tinggi pada wanita dibandingkan pria.

Menurut data dari P2P Dinas Kesehatan Kota Makassar, pada tahun 2017 prevalensi hipertrigliserida sebesar 40,13\% dan mengalami peningkatan pada tahun 2018 prevelansi 
hipertrigliserida sebesar 43,70\% ${ }^{3}$. Prevalensi obesitas sentral di Kota Makassar tahun 2018 tertinggi Puskesmas Bara-Baraya sebesar 96, 55\%, disusul Puskesmas Antara sebesar 63,3\% selanjutnya Puskesmas Pampang sebesar 56,3\% ${ }^{3}$. Penelitian yang dilakukan Sudikno, dkk bahwa obesitas sentral pada orang dewasa umur 25-65 berhubungan dengan profil lipid setelah dikontrol variabel jenis kelamin, umur, dan kebiasaan merokok ${ }^{4}$. Salah satu pencegahan agar kadar trigliserida tidak meningkat adalah dengan mengkonsumsi herbal seperti kayu manis. Penelitian yang dilakukan oleh Richard A. Anderson, et all di clinic of the General Hospital of the 2nd Artillery, Beijing Tang-An Clinic and Dalian Dakang Clinic, in Beijing and Dalian, China, tahun 2015, dengan mengkonsumsi ekstrak kayu manis 500 mg per hari dapat menurunkan kadar glukosa, insulin dan kolesterol ${ }^{4}$.

Penelitian yang dilakukan oleh Hossein Khadem Haghighian, Alireza Farzad Naimi, Bharam Pourghassem Gargari, Akbar Ali-Asgharzadeh, Ali Nemati pada Endocrinology and Diabetes Clinic of Tabriz University of Medical Sciences, di Iran pada tahun 2010 bahwa rata-rata kadar glukosa darah puasa, kolesterol total, kolesterol LDL dan kadar trigliserida menurun setelah konsumsi bubuk kayu manis, secara signifikan $(p<0,05)^{5}$. Penelitian yang dilakukan oleh Abdul Rahim Al Jamal tahun 2009 di Al Mafraq Governmental Hospital Jordan tentang kayu manis terhadap kadar trigliserida, total kolesterol dan LDL menunjukkan hasil signifikan $\mathrm{p}<0,05$, dengan dosis $3 \times 2$ gr dalam bentuk kapsul selama 4 minggu 5 .

Penelitian yang dilakukan oleh Tim, dkk dengan menggunakan ekstrak kayu manis pada laki-laki dan wanita pre diabetes dengan ciri-ciri metabolik sindrom secara statistik penurunan lemak tubuh yang signifikan $(-0,7 \%$ : $37,9 \pm 9,2 \%$ [pra] menjadi $37,2 \pm 8,9 \%$ [posting], $\mathrm{p}<0,02$ ) dalam kelompok Cinnulin PF® (ekstrak kayu manis larut air) ${ }^{6}$.

Berdasarkan uraian latar belakang di atas, peneliti tertarik untuk meneliti tentang "Efek rebusan batang kayu manis terhadap perubahan kadar trigliserida pada prediabetes di Kota Makassar".

\section{BAHAN DAN METODE}

Lokasi penelitian di wilayah Puskesmas Kota Makassar, penelitian kuantitatif dengan quasi ekserimen. Model rancangan adalah non randomized pre test post test with control group. Penelitian ini menggunakan 1 kelompok intervensi yaitu kelompok I (pemberian rebusan kayu manis dan edukasi kayu manis) dan kelompok kontrol yaitu kelompok II (pemberian edukasi kayu manis).

Populasi: penelitian yaitu masyarakat di wilayah Puskesmas Makassar dengan sampel penelitian yaitu masyarakat di wilayah Puskesmas Antara, dan Pampang Makassar yang memenuhi kriteria inklusi dan ekslusi. Teknik sampling: Purposive sampling yaitu teknik penentuan sampel berdasarkan teknik tertentu yaitu sesuai kriteria inklusi.. Sampel yang memenuhi kriteria inklusi yaitu gula darah puasa $100-125 \mathrm{mg} / \mathrm{dl}$, tidak mengkonsumsi obat yang bisa mempengaruhi kadar gula darah dan trigliserida, dan bersedia mengkonsumsi rebusan kayu manis selama 14 hari.

Cara merekrut sampel adalah melakukan skrining dengan cara pemeriksaan GDP dan yang sesuai dengan kriteria sampel baik pada kelompok intervensi maupun kelompok kontrol dimana sampai berjumlah 34 sampel yang terdiri dari satu kelompok intervensi dan satu kelompok kontrol. Sebelum mengambil glukosa darah puasa, responden diharuskan berpuasa selama 8-10 jam. Pengambilan darah dilakukan oleh petugas PRODIA Makassar, dengan 
metode pengambilan darah pada vena siku dalam tangan subjek sebanyak 3-5 mL, kemudian dianalisa secara langsung dengan menggunakan mesin analisis darah.

Dari 34 sampel diukur antropometri, lingkar perut, kemudian dibagi untuk kelompok intervensi dan kelompok kontrol. Asupan makanan direcall pada kedua kelompok sebelum dan sesudah penelitian, demikian juga dengan trigliserida darah dan antropometri. Sampel sampai hari ke 14 sebanyak 31 orang karena ada 3 drop out. Data dianalisis menggunakan SPSS versi 21. Untuk melihat kadar trigliserida dan HDL dilakukan tes laboratorium, Untuk menguji distribusi normal dilakukan uji normalitas Saphiro-Wik. Uji T test berpasangan digunakan untuk menguji hipotesis komparatif rata-rata dua sampel dan berdistribusi normal. Untuk mengetahui perbedaan dua kelompok digunakan uji T Independen.

\section{HASIL}

Berdasarkan hasil penelitian diketahui mayoritas responden kedua kelompok perempuan yaitu 25 orang $(93,8 \%)$ kelompok intervensi dan 13 orang $(86,7 \%)$ kelompok kontrol. Sementara berdasarkan usia, pada kedua kelompok umur masing-masing responden 14 orang (50\%) Karakteristik berdasarkan lingkar perut, mayoritas responden pada kedua kelompok mengalami obesitas sentral sebanyak 26 orang $(92,85 \%)$.

Tabel 1. Distribusi Responden Berdasarkan Karakteristik Jenis Kelamin, Usia, Lingkar Perut, Riwayat Keluarga DM, dan Pendidikan

\begin{tabular}{llcccc}
\hline \multirow{2}{*}{ Variabel } & \multicolumn{1}{c}{ Kategori } & \multicolumn{2}{c}{$\begin{array}{c}\text { Kelompok } \\
\text { Intervensi }\end{array}$} & \multicolumn{2}{c}{ Kelompok Kontrol } \\
\cline { 3 - 6 } & & $\mathbf{N}$ & $\mathbf{\%}$ & $\mathbf{N}$ & $\mathbf{\%}$ \\
\hline \multirow{3}{*}{ Jenis Kelamin } & Laki-Laki & 1 & 7,1 & 2 & 14,3 \\
& Perempuan & 13 & 92,9 & 12 & 85,7 \\
& Total & $\mathbf{1 4}$ & $\mathbf{1 0 0}$ & $\mathbf{1 4}$ & $\mathbf{1 0 0}$ \\
\hline \multirow{3}{*}{ Usia } & Dewasa (40-50) & 6 & 21,4 & 8 & 28,6 \\
& Usila (51-60) & 8 & 28,6 & 6 & 21,4 \\
& Total & $\mathbf{1 4}$ & $\mathbf{1 0 0}$ & $\mathbf{1 4}$ & $\mathbf{1 0 0}$ \\
\hline \multirow{3}{*}{ Lingkar Perut } & Non Obesitas Sentral & 13 & 93.8 & 13 & 86.7 \\
& Total & 1 & 6.3 & 1 & 13.3 \\
\multirow{2}{*}{ Kiwayat } & Ada & $\mathbf{1 4}$ & $\mathbf{1 0 0}$ & $\mathbf{1 4}$ & $\mathbf{1 0 0}$ \\
\cline { 2 - 6 } & Tidak Ada & 9 & 62.5 & 11 & 73.3 \\
& Total & 5 & 25 & 3 & 20 \\
& SD & $\mathbf{1 4}$ & $\mathbf{1 0 0}$ & 14 & $\mathbf{1 0 0}$ \\
\hline \multirow{3}{*}{ Pendidikan } & SMP & 3 & 18,8 & 3 & 20 \\
& SMA & 4 & 31,3 & 2 & 20 \\
& Akademi/PT & 3 & 25,0 & 1 & 6,7 \\
& Total & 4 & 14,28 & 8 & 28,57 \\
\hline
\end{tabular}

Sumber: Data Primer, 2019 
Sebagian besar responden pada kedua kelompok memiliki riwayat keluarga DM yakni sebanyak 10 orang $(62,5 \%)$ pada kelompok intervensi dan 11 orang $(73,3 \%)$ pada kelompok kontrol. Karakteristik pendidikan responden, mayoritas Akademi/perguruan tinggi 12 orang $(42,85 \%)$.

Berdasarkan hasil uji normalitas dengan menggunakan uji Shapiro-Wik karena sampel di bawah 50, nilai $\mathrm{df}=14$, maka diketahui nilai $\mathrm{p}$ value untuk kadar trigliserida $>0,05$, artinya berdistribusi normal.

Tabel 2. Uji Normalitas kadar Trigliserida dan HDL Responden (n=28)

\begin{tabular}{clcl}
\hline & \multicolumn{1}{c}{ Variabel } & df & p value* \\
\hline \multirow{4}{*}{ Trigliserida } & Trigliserida kelompok intervensi pre & 14 & 0,491 \\
\cline { 2 - 4 } & Trigliserida kelompok kontrol pre & 14 & 0,658 \\
\cline { 2 - 4 } & Trigliserida kelompok intervensi post & 14 & 0,857 \\
\cline { 2 - 5 } & Trigliserida kelompok kontrol post & 14 & 0,010 \\
\hline
\end{tabular}

Sumber: Data Primer, 2019

Berdasarkan data terlihat bahwa rata-rata trigliserida darah pada kelompok yang diberikan rebusan kayu manis pre test 192,93 mg/dl dan post test $170,57 \mathrm{mg} / \mathrm{dl}$ dengan nilai $\mathrm{p}$ value 0,109>0,05 yang berarti tidak ada perbedaan trigliserida sebelum dan setelah diberikan intervensi rebusan kayu manis. Sementara pada kelompok yang diberikan edukasi saat pre test adalah $128,79 \mathrm{mg} / \mathrm{dl}$ dan post test adalah 149,64 mg/dl dengan nilai $\mathrm{p}$ value 0 0,279>0,05 yang berarti tidak ada perbedaan trigliserida sebelum dan setelah diberikan edukasi. Namun berdasarkan uji $\mathrm{T}$ tidak ber pasangan, $\mathrm{p}$ value untuk trigliserida adalah 0,527 yang berarti tidak signifikan. Akan tetapi jika dilihat dari selisih rata-rata penurunan trigliserida darah pada kedua kelompok, kelompok yang diberikan rebusan kayu manis memiliki rata-rata penurunan yang lebih besar yaitu 22,36 mg/dl.

Tabel 3. Analisis Trigliserida sebelum dan setelah intervensi pada kedua kelompok

\begin{tabular}{|c|c|c|c|c|c|c|c|c|c|c|}
\hline \multirow{3}{*}{$\begin{array}{c}\text { Variab } \\
\text { el }\end{array}$} & \multicolumn{3}{|c|}{ KI } & \multirow{3}{*}{$\begin{array}{c}\mathbf{P} \\
\text { Val } \\
\text { ue }\end{array}$} & \multicolumn{3}{|c|}{ KK } & \multirow{3}{*}{$\begin{array}{c}\mathbf{P} \\
\text { Valu } \\
\mathbf{e}\end{array}$} & \multirow{3}{*}{$\begin{array}{c}\text { P } \\
\text { Value } \\
\text { pre (KI } \\
\text { KK) }\end{array}$} & \multirow{3}{*}{$\begin{array}{c}\text { P Value } \\
\text { post (KI } \\
\text { KK) }\end{array}$} \\
\hline & Pre & Post & $\Delta$ & & \multirow{2}{*}{$\begin{array}{c}\text { Pre } \\
\text { Mea } \\
\mathbf{n} \pm \\
\text { SD }\end{array}$} & \multirow{2}{*}{$\begin{array}{c}\text { Post } \\
\text { Mea } \\
\text { n } \pm \\
\text { SD }\end{array}$} & \multirow{2}{*}{$\begin{array}{c}\Delta \\
\text { Mean } \\
\pm \text { SD }\end{array}$} & & & \\
\hline & $\begin{array}{c}\text { Mean } \\
\pm \text { SD }\end{array}$ & $\begin{array}{c}\text { Mea } \\
\text { n } \pm \\
\text { SD }\end{array}$ & $\begin{array}{l}\text { Mean } \\
\pm \text { SD }\end{array}$ & & & & & & & \\
\hline & 192,9 & 170 & $\downarrow 22,3$ & & 128 & 149,6 & $\uparrow 20,8$ & & & \\
\hline $\begin{array}{l}\text { erida } \\
\text { (mg/dl) }\end{array}$ & $\begin{array}{c}3 \pm \\
95,87\end{array}$ & $\begin{array}{l}57 \pm \\
75,8\end{array}$ & $\begin{array}{c}6 \pm \\
20,01\end{array}$ & $\begin{array}{c}0,10 \\
9 *\end{array}$ & $\begin{array}{l}79 \pm \\
83,5\end{array}$ & $\begin{array}{c}4 \pm \\
85,38\end{array}$ & $\begin{array}{c}5 \pm \\
1,866\end{array}$ & $\begin{array}{c}0,27 \\
9 *\end{array}$ & $0,040 * *$ & $0,449 * *$ \\
\hline & 6 & 59 & 7 & & 24 & 6 & & & & \\
\hline
\end{tabular}

Sumber: Data Primer, 2019

Ket: KI: Kelompok Intervensi

KK: Kelompok Kontrol 
Berdasarkan penelitian, terlihat bahwa rata-rata pengetahuan pada kelompok yang diberikan intervensi, edukasi pre test 70,407 dan post test 87,09 dengan nilai $p$ value $0,000<$ 0,05 yang berarti ada perbedaan pengetahuan sebelum dan setelah diberikan edukasi. Sementara pada kelompok yang diberikan kontrol, edukasi saat pre test adalah 71,60 dan post test adalah 82,49 dengan nilai p value $0 `, 000<0,05$ yang berarti ada pengaruh pengetahuan sebelum dan setelah diberikan edukasi.

Tabel 4. Distribusi Responden Berdasarkan Rata-rata Asupan Zat Gizi Sebelum dan Setelah Intervensi pada Kelompok Rebusan Kayu Manis

\begin{tabular}{lccc}
\hline \multirow{2}{*}{ Asupan Zat Gizi } & \multicolumn{1}{c}{ Pre Test } & Post Test & $\begin{array}{c}\text { P } \\
\text { Value* }\end{array}$ \\
\cline { 2 - 3 } & Rata-rata \pm SD & Rata-rata \pm SD & \\
\hline Energi (kkal) & $1355,18 \pm 783,706$ & $1258,82 \pm 848,253$ & 0,580 \\
Karbohidrat (g) & $197,90 \pm 101,669$ & $207,13 \pm 182,691$ & 0,761 \\
Protein (g) & $44,53 \pm 17,410$ & $48,66 \pm 36,011$ & 0,601 \\
Lemak (g) & $43,04 \pm 42,946$ & $38,85 \pm 35,982$ & 0,594 \\
Serat (g) & $6,28 \pm 2,498$ & $9,82 \pm 8,880$ & 0,160 \\
\hline
\end{tabular}

Sumber: Data Primer, 2019

Berdasarkan uji $\mathrm{T}$ tidak berpasangan, $\mathrm{p}$ value untuk pengetahuan adalah 0,001 yang berarti signifikan. Akan tetapi jika dilihat dari selisih rata-rata peningkatan pengetahuan pada kedua kelompok, kelompok yang diberikan intervensi memiliki rata-rata peningkatan pengetahuan yang lebih besar yaitu 16,68.

Tabel 5.Distribusi Responden Berdasarkan Rata-rata Asupan Gizi Sebelum dan Setelah Edukasi pada Kelompok Kontrol

\begin{tabular}{lccc}
\hline \multirow{2}{*}{ Asupan Zat Gizi } & \multicolumn{1}{c}{ Pre Test } & Post Test & $\begin{array}{c}\text { P } \\
\text { Value }\end{array}$ \\
\cline { 2 - 3 } & Rata-rata \pm SD & Rata-rata \pm SD & \\
\hline Energi (kkal) & $1151,65 \pm 619,626$ & $951,53 \pm 489,41$ & 0,221 \\
Karbohidrat (g) & $150,06 \pm 71,336$ & $140,35 \pm 47,087$ & 0,538 \\
Protein (g) & $40,61 \pm 24,591$ & $39,50 \pm 22,726$ & 0,913 \\
Lemak (g) & $38,30 \pm 40,453$ & $24 \pm 23,182$ & 0,202 \\
Serat (g) & $3,99 \pm 2,345$ & $3,49 \pm 2,083$ & 0,566 \\
\hline
\end{tabular}

Sumber: Data Primer, 2019 
Tabel 6. Analisis Pengetahuan sebelum dan setelah edukasi pada kedua kelompok

\begin{tabular}{|c|c|c|c|c|c|c|c|c|c|c|}
\hline \multirow[b]{3}{*}{ Variabel } & \multicolumn{3}{|c|}{ KI } & \multirow{3}{*}{$\begin{array}{c}\mathbf{P} \\
\text { Val } \\
\text { ue }\end{array}$} & \multicolumn{3}{|c|}{ KK } & \multirow{3}{*}{$\begin{array}{c}\mathbf{P} \\
\text { Val } \\
\text { ue }\end{array}$} & \multirow{3}{*}{$\begin{array}{c}\text { P Value } \\
\text { pre }(K I \\
\text { dan } K K)\end{array}$} & \multirow{3}{*}{$\begin{array}{l}\text { P Value } \\
\text { post }(K I \\
\text { dan } K K)\end{array}$} \\
\hline & Pre & Post & $\Delta$ & & Pre & Post & $\Delta$ & & & \\
\hline & $\begin{array}{c}\text { Mea } \\
\text { n } \pm \\
\text { SD }\end{array}$ & $\begin{array}{l}\text { Mea } \\
\mathbf{n} \pm \\
\text { SD } \\
\end{array}$ & $\begin{array}{l}\text { Mean } \\
\pm \text { SD }\end{array}$ & & $\begin{array}{c}\text { Mea } \\
\mathbf{n} \pm \\
\text { SD } \\
\end{array}$ & $\begin{array}{c}\text { Mea } \\
\mathbf{n} \pm \\
\text { SD } \\
\end{array}$ & $\begin{array}{l}\text { Mea } \\
\mathbf{n} \pm \\
\text { SD }\end{array}$ & & & \\
\hline $\begin{array}{l}\text { Pengetah } \\
\text { uan }\end{array}$ & $\begin{array}{c}70,40 \\
7 \pm \\
8,609\end{array}$ & $\begin{array}{c}87,0 \\
9 \pm \\
7,30 \\
6\end{array}$ & $\begin{array}{c}\uparrow 16,6 \\
83 \pm \\
1,303\end{array}$ & $\begin{array}{c}0,00 \\
0\end{array}$ & $\begin{array}{l}71,6 \\
0 \pm \\
6,92 \\
8\end{array}$ & $\begin{array}{c}82,4 \\
9 \pm \\
8,09 \\
6\end{array}$ & $\begin{array}{c}\uparrow 8,8 \\
717 \\
\pm \\
1,16 \\
8\end{array}$ & $\begin{array}{c}0,00 \\
0\end{array}$ & $0,372 *$ & $0,001 *$ \\
\hline
\end{tabular}

Sumber: Data Primer, 2019

\section{PEMBAHASAN}

Mayoritas responden kedua kelompok perempuan yaitu 15 orang $(93,8 \%)$ kelompok intervensi dan 13 orang $(86,7 \%)$ kelompok kontrol. Hal ini disebabkan mayoritas pekerjaan perempuan adalah ibu rumah tangga tidak beraktifitas di luar rumah. Hal ini dibuktikan dengan penelitian yang dilakukan oleh Nisya Desyaningrum, et al tahun 2014 di FKM Bogor responden prediabetes sebagian besar perempuan ${ }^{7}$.

Sementara berdasarkan usia, mayoritas responden berusia antara 51-60 tahun pada kelompok intervensi 10 (56,4\%), sedangkan kelompok kontrol mayoritas umur 40 - 50 tahun sebanyak 8 orang $(54,2 \%)$. Penelitian yang dilakukan oleh Ani Astuti bahwa prediabetes banyak diderita pada umur $<45$ tahun sebesar 73,1 \% (Astuti et al., 2019) . Usia merupakan faktor resiko yang tidak dapat dimodifikasi menderita prediabetes, sehingga prevalensi prediabetes meningkat seiring dengan bertambahnya usia ${ }^{7}$.

Karakteristik berdasarkan lingkar perut, mayoritas responden mengalami obesitas sentral sebanyak 26 orang $(92,85 \%)$ dan yang tidak mengalami obesitas sentral sebanyak 2 orang $(0,07 \%)$. Risiko penyakit DM tipe 2 meningkat bersamaan dengan peningkatan indeks massa tubuh, rasio pinggul terhadap pinggang, dan penimbunan lemak terpusat.

Penelitian oleh Sudikno, et all bahwa obesitas sentral pada orang dewasa umur 26-65 tahun berhubungan dengan profil lipid setelah dikontrol variabel jenis kelamin, umur, dan kebiasaan merokok ${ }^{8}$.

Hasil uji $\mathrm{t}$ independen berpasangan tidak ada perbedaan sebelum dan sesudah intervensi dan edukasi pada kedua kelompok untuk asupan energi. Hal ini berbeda dengan teori yang ada. Karena kemungkinan responden mengatur pola makannya karena mau diperiksa darahnya. Pada kelompok intervensi asupan energi diketahui bahwa baik pada waktu pre asupan energi rata-rata $1355,18 \mathrm{kkal}$ menurun pada post yaitu rata-rata 1258,82 kkal. Demikian juga pada kelompok kontrol mengalami penurunan, energi jika berlebihan akan mempengaruhi kerja insulin dan akan meningkatkan trigliserida yang bertugas menyimpan energi dari makanan ${ }^{9}$.

Asupan Karbohidrat pada kelompok intervensi mengalami kenaikan, tetapi pada kelompok kontrol mengalami penurunan. Karbohidrat dibutuhkan dalam jumlah cukup, jika berlebihan menyebabkan berat badan berlebihan yang dapat memicu prediabetes. 
Asupan lemak pada kedua kelompok juga menurun di bawah persen AKG. Untuk memilih lemak yang tidak jenuh. Karena lemak ini adalah lemak sehat dan juga bisa menurunkan resiko penyakit jantung 9 .

Asupan serat pada kelompok intervensi meningkat tetapi menurun pada kelompok kontrol. Serat lebih efektif menurunkan kadar trigliserida.

Berdasarkan data dapat diketahui bahwa baik dari kelompok intervensi maupun kelompok kontrol ada perbedaan sebelum dan sesudah diberikan intervensi dan edukasi dengan nilai $\mathrm{p}$ value $0,000<0,05$ pada uji t. Hal ini berdasarkan dengan meningkatnya pengetahuan setelah diberikan edukasi. Ini sesuai dengan penelitian Kristanti, et all bahwa edukasi dapat meningkatkan pengetahuan pada prediabetes dengan nilai p 0,003 (Kristanti, 2016).

\section{KESIMPULAN}

Kesimpulan tidak ada perubahan kadar trigliserida yang signifikan sebelum dan sesudah konsumsi rebusan kayu manis pada prediabetes. Untuk penelitian berikutnya diharapkan menambah dosis kayu manis dan pemberiaannya lebih lama agar pemberian rebusan kayu manis efektifitas

\section{DAFTAR PUSTAKA}

1. Profiles, C. Noncommunicable Diseases. 2018.

2. International Diabetes Federation (IDF). IDF Diabetes Altas. Eighth edition 2017, IDF Diabetes Atlas, 8th edition [Internet]. 2017; Available at doi: http://dx.doi. org/10.1016/S0140-6736(16)31679-8.

3. P2P, P. Dinas Kesehatan Kota Makassar: Kota Makassar. 2018

4. Anderson, R. A. et al. Cinnamon extract lowers glucose, insulin and cholesterol in people with elevated serum glucose', Journal of Traditional and Complementary Medicine. Elsevier Ltd [Internet]. 2016; 6(4):332-336. Available at :doi: 10.1016/j.jtcme.2015.03.005.

5. Haghighian, H. K., Naimi, A. F. and Gargari, B. P. Effect of cinnamon supplementation on blood glucose and lipid levels in type2 diabetic patients. 2011; 2(1): 2-6.

6. Ziegenfuss, T. N. et al. Effects of a Water-Soluble Cinnamon Extract on Body Composition and Features of the Metabolic Syndrome in Pre-Diabetic Men and Women. 2006; 3(2):45-53.

7. Deyasningrum, N. et al. Faktor Dominan Terhadap Kejadian Pre Diabetes Mellitus dan Diabetes Mellitus Tipe 2 Pada Staf Kependidikan FKM UI Depok Tahun. 2014.

8. Sudikno. Hubungan Obesitas sentral dengan profil lipid pada orang dewasa umur 25-65 tahun di Kota Bogor. Journal of The Indonesian Nutrition Association [Internet]. 2016;39:81-92. Available at: http://ejournal.persagi.org/go/.

9. Noviya R. Makanan-makanan tinggi Kolesterol. FlashBooks. Yogyakarta; 2015. 